\title{
Neoliberalism and East Asia: Resisting the Washington Consensus
}

\author{
Mark Beeson and Iyanatul Islam
}

Abstract

This paper explores the way neoliberal ideas have been promoted and resisted in East Asia. The core argument of this paper is that the contest of ideas in economic policymaking can evolve independently of their intellectual merit and empirical credibility. Political interests shape and mediate the process. In the case of post-crisis East Asia, the notion that the political economies of the region need to be fundamentally reformed to re-ignite the 'economic miracle' of the pre-crisis era does not stem from a politically neutral, dispassionate and intellectually rigorous analyses of what went wrong in the recession-inducing 1997 financial crisis that engulfed the region. It represents an attempt to re-invent orthodoxy in the domain of economic ideas and ideology by the global policy community that in turn bears the inordinate influence of US-centric institutions.

Current debates over the future direction of the reform agenda in post-crisis East Asia have to be set in the broader context of the global debate on the role of ideas and ideology in shaping economic policy-making. Certain ideas gain primacy at one stage and seem to fade at another juncture. The core argument of this paper is that the contest of ideas in economic policy-making can evolve independently of their intellectual merit and empirical credibility. Political interests shape and mediate the process. In the case of post-crisis East Asia, the notion that the political economies of the region need to be fundamentally reformed to re-ignite the 'economic miracle' of the pre-crisis era does not stem from a politically neutral, dispassionate and intellectually rigorous analyses of what went wrong in the recession-inducing 1997 financial crisis that engulfed the region. It represents an attempt to re-invent orthodoxy in the domain of economic ideas and ideology by the global policy community that in turn bears the inordinate influence of US-centric institutions.

This proposition is developed in a number of ways. First, the paper delineates the conservative economic and political agenda of what is often called neoliberalism. The latter preaches the primacy of the market economy in engendering and sustaining economic prosperity. In propagating such a view, it poses a direct challenge to the values and ethos of 'regulated capitalism' that held sway in the industrialised countries of the OECD for at least two decades after the Second World War. The ascendency of conservative political forces towards the end of the 1970s in the United States and the United Kingdom undoubtedly played a role in the intellectual ascendency of neoliberalism.

The 1980s and 1990s cemented the rise of neoliberalism even as a professional consensus appeared to emerge that markets alone could not explain rapid East Asian economic growth in the pre-crisis era and that institutional variables played an important, and perhaps even a decisive, role. As Chomsky (1993) argues, the end of the Cold War unleashed the hegemonic impulse of the United States, while the onset of the long economic boom in the 1990s under the Clinton administration lent a degree of legitimacy to a global project of 'exporting' neoliberal ideas to the rest of 
the world. The Bretton Woods institutions - represented by the Washington-based World Bank and the IMF - turned out to be the principal conduit for the transmission of neoliberal ideas to the developing countries. Williamson $(1990,1994)$ became famous for celebrating this proselytising role of the Bank and the IMF. He suggested that these institutions, in conjunction with the US Treasury, represented the

'Washington consensus' on what constituted 'good' economic policies. The Washington Consensus eventually became a global policy mantra. Yet, the legitimacy of the Washington Consensus is now being questioned.

Several factors and events have combined to force a re-thinking of the original tenets of neoliberalism. These include the perceived mishandling of the East Asian crisis by the Bretton Woods institutions. The termination of the long economic boom of the 1990s in the United States and a series of corporate scandals that has tarnished the image of American capitalism also dented the potency of a US-led global project to propagate neoliberalism across the world. ${ }^{1}$ The tragedy of 'fast-tracking' capitalism in Eastern Europe and the ex-Soviet Union, the failure of the neoliberal experiment in Latin America and the highly circumspect nature of the evidence on global growth, inequality and poverty have turned out to be influential in restraining the rise of neoliberalism. ${ }^{2}$ What one is witnessing is a re-invention of global neoliberalism under the guise of an 'augmented Washington consensus'.

The paper counsels caution in embracing this modified version of global neoliberalism, even if domestic political forces in East Asia turn out to be receptive to the adoption of such ideas. It suggests that elements of the pre-crisis East Asian development strategy still has contemporary relevance, while new - and more assertive - forms of regional cooperation that has emerged in the wake of the 1997 crisis deserve greater attention. At the same time, an enabling global environment is crucial in supporting national policy initiatives in post-crisis East Asia.

\section{The evolution of neoliberalism}

As noted, neoliberalism preaches the primacy of a market economy (combined with a limited role of the government) in engendering and sustaining economic prosperity a proposition that is supposed to be valid across both time and space. Not surprisingly, some commentators, such as Stiglitz (2002) and Soros (1998), use the term 'market fundamentalism' as a synonym for neoliberalism. The latter also espouses a conservative political agenda in which the political leadership should attenuate the activism of civil society and allow technocrats the discretion, freedom and scope to pursue the neoliberal economic agenda. This stems from a world-view in which rentseeking lobbyists, keen on acquiring special privileges and protection from the government, populate society.

Neoliberals display an aversion to significant government intervention in a market economy. They adhere to an analytical framework in which government activism is either a reflection of the innate predatory instincts of the state or the basis for creating opportunities for rent-seeking interests to emerge that ultimately 'capture' the policymaking process to suit their partisan ends. ${ }^{3}$

Neoliberalism marks a significant departure from the ideas and ideology that guided the international order that emerged in the wake of the Second World War. The 
structures of liberal governance created primarily under United States auspices in the immediate aftermath of World War II provided an overarching geopolitical and regulatory framework within which capitalism flourished. Crucially, however, as Ruggie [1982: 379-415] famously pointed out, despite the increasingly pervasive influence and reach of the so-called Bretton Woods institutions that were established at this time, the emergent liberal order was premised on the retention of a high degree of domestic autonomy. State intervention in the market economy to attain specific economic ends (most notably full employment) was widely regarded as a legitimate political aspiration. The compromise of 'embedded liberalism' meant that individual governments retained a good deal of independence in the management of the domestic economy, something that led to very different patterns of political relationships and economic structures. The Cold War environment, which provided a compelling strategic impetus for capitalist consolidation, not only provided a conducive environment for the successful resurrection of liberal capitalism generally [Latham 1997], it also facilitated the development of very different types of capitalism that persist to this day [Berger and Dore 1996; Coates 2000].

In the first couple of decades after World War II, the so-called 'golden age' of capitalism [Glyn 1990: 39-119], Keynesian policies were the accepted orthodoxy and dominant policy paradigm. Across the capitalist world, 'interventionist' macroeconomic policy was considered a necessary part of responsible economic management. A number of factors helped undermine the pre-eminent position of Keynesian ideas and pave the way for a transition initially to monetarism and subsequently to a more broadly based neoliberal agenda. First, the breakdown of the managed system of exchange rates associated with the original Bretton Woods agreements and the subsequent exponential growth of financial markets meant that domestic policy-making autonomy had been undermined. Second, a series of interconnected economic crises in the 1970s revolving around the inflationary impact of rising oil process, a fiscal crisis of the state, and rising unemployment, led many to consider the Keynesian model to be exhausted and no longer appropriate. Over time, a great deal of emphasis was placed on fighting inflation as the core responsibility of governments, while the need to sustain full employment was no longer regarded as an explicit macroeconomic policy goal. It was argued that, once stable prices prevailed, a market economy had self-correcting properties and did not require Keynesian activism to cure recessions.

Neoliberalism was enthusiastically and effectively promoted by an influential group of 'policy entrepreneurs' who were ultimately able to obtain the formidable political support of Margaret Thatcher in Britain and Ronald Reagan in the US [Crockett 1994]. The combination of seemingly ineffective Keynesian policies and an enthusiastically supported alternative model meant that the preconditions for a fundamental paradigm shift were in place. Crucially, however, as Peter Hall has pointed out [1993: 275-96; 1986], it required the application of political power to overcome the institutionalised obstacles to reform that threatened to block the transition to a new ruling economic orthodoxy.

In much of East Asia, not only is the support for a similar paradigm shift and wholesale embrace of neoliberalism generally less evident, but potential obstacles to reform remain entrenched. As a number of observers have pointed out [Beeson 2002: 7-27; Hall 1986; Zysman 1994: 243-83], 'history matters', because the historically 
specific circumstances within which policy is constructed and applied necessarily delimit what is acceptable and feasible. ${ }^{4}$ Even if it could be demonstrated that neoliberal policies are in some way 'better' or more appropriate than the state-led economic policies that have been the norm across much of East Asia - and, as we shall see, this is highly unlikely - such policy initiatives will not be taken up in the absence of adequate political backing. Given that much of the neoliberal agenda directly threatens existing patterns of political and economic power across much of the region, there is no reason to suppose that neoliberal policies will be enthusiastically taken up - especially if there are continuing doubts about the merits and possible impact of the neoliberal paradigm. Before considering the basis of such reservations, it is important to briefly spell out how the neoliberal model was 'exported' to the rest of the world under the guise of the Washington consensus and how this global project has undergone significant modifications.

\section{Neoliberalism and the Washington consensus}

The diffuse array of ideas associated with neoliberalism was given more precise expression by John Williamson [1994: 11-28] who termed the expression Washington consensus to describe the economic orthodoxy that prevailed in the US Treasury Department and in key IFIs like the World Bank and the IMF. Much of what Williamson described as 'the technocrats agenda' became the familiar staples of contemporary policy-making - amongst the Anglo-American economies at least.

The original Washington consensus, which Williamson described as the "common core of wisdom embraced by all serious economists' consists of the first 10 points outlined in Table 1. Much of this has become the widely recognised bedrock of the market-oriented reform agenda that emerged in Britain and America during the 1980s. The 'ten commandments' in Table 1 are meant to roll back the reach of the state. Thus, governments, in both rich and poor nations, are urged to practice 'macroeconomic prudence' (a euphemism for the control of inflation and for maintaining tight budgets), deregulation, privatisation and economic liberalisation (primarily through both trade and capital account liberalisation). There are, of course, references to restructuring government budgetary priorities for sustaining social spending in basic health and education, but, as Williamson (1999) himself concedes, this proposition is typically neglected in practice. ${ }^{5}$

The Washington Consensus has, in recent years, mutated into the 'augmentedWashington Consensus' [AWC], in which the original agenda has been supplemented by a concern with poverty reduction and a range of 'governance' issues, outlined in points 11-20 in Table 1. ${ }^{6}$ The pre-requisites of 'good' governance revolve around democratic reform, the promotion of civil society, institution and capacity building, transparency, a renewed commitment to poverty reduction, and the creation of social safety nets. It is clear that the emphasis on the promotion of civil society in the 'augmented' version of the Washington consensus represents a significant attempt to differentiate itself from the original neoliberal political agenda of restraining the activism of civil society on the ground that the latter is populated by rent-seeking lobbyists. 
The initial mishandling of the East Asian crisis by the IMF, and the failure of a predicted ' $\mathrm{V}$-shaped' recovery from the recessions that followed in the wake of the 1997 financial crisis, has had the effect of accelerating the consolidation of an AWC. In general, earlier certainties about the wisdom of financial sector reform that was a core plank of IMF-led rescue efforts in East Asia are being subjected to widespread critiques [Jayasuriya and Rosser 2001: 381-96]. Yet, despite this apparent willingness to consider the circumstances within which reform occurs, there is little recognition of the politically contested nature of the economic reform process. As Higgott [2000: 131-53] observes, 'to the extent that the international institutions recognise that political resistance is a legitimate part of the governance equation, it is a problem to be solved. It is not seen as a perpetual part of the process' [Higgott 2000: 144, emphasis in original].

\section{Re-inventing neoliberalism in East Asia}

Despite the failure of the Washington consensus to recognise the inherently political nature of reform, a crucial question is whether the East Asian crisis is in fact a vindication of the basic tenets of the neoliberal reform agenda. If so, does this mean that post-crisis East Asia will have to embrace these tenets as a means of re-igniting the 'miracle' years of the pre-1997 period? This section of the paper suggests that, far from vindicating the core propositions of neoliberalism, the recent economic history of East Asia, as well as global economic events and a burgeoning dissident literature, suggest otherwise. Indeed, there is a compelling case for East Asian policy-makers to re-affirm the faith in the many institutional variants of a mixed economy model rather than a universalistic 'one-size-fits-all' recipe for policy reform, even in the current 'augmented' Washington consensus version. Furthermore, there is a persuasive case for East Asian policy-makers to collectively put their weight behind recent calls for the reform of global economic governance and enhanced regional cooperation. These, we argue, are necessary steps for creating an environment in which the crisis-affected economies of East Asia, in common with other developing countries, can craft their own distinctive and country-specific path to sustainable and equitable development.

\section{Neoliberalism in East Asia- A critique}

The consensus that was reached on understanding East Asian development and the lessons that one could draw from it broke down in the wake of the 1997 financial crisis. $^{7}$ Pundits - most notably the IFIs which, on the very eve of the crisis, praised the East Asian economies for their 'miraculous' achievements - now rushed to condemn them as 'failed' cases of 'crony capitalism'. What appeared to be close governmentbusiness relations that were, in the past, argued to facilitate a virtuous process of equitable growth now became 'corrupt' regimes that encouraged inefficient state intervention, bred structural deficiencies and brought about their own downfall. The solution - crafted through the so-called 'Letters of Intent' that were negotiated between the IMF and the crisis-affected economies of Indonesia, Thailand and Korea - essentially called for a re-imposition of 'augmented' Washington Consensus policies. In other words, the core policy proposals pertaining to macroeconomic prudence, deregulation, privatisation and liberalisation now had to be supplemented by a renewed commitment to poverty reduction and wide-ranging institutional reform that fell under the rubric of 'good governance'. As noted, Table 1 captures the essence of this 'augmented' version of the Washington consensus. Indeed, one could 
argue that the attempt to reform the crisis-affected economies in East Asia simply became an experiment in re-inventing neoliberalism in the region.

It is ironic that the attempt by the advocates of the Washington consensus to rehabilitate neoliberalism in East Asia is occurring at a juncture when there are considerable concerns about recent global and regional economic trends. It is ironic too that the attempt to forge a 'new' consensus on 'best-practice' norms in economic policy-making is coinciding with rising voices of dissent within the economics profession. Such dissidents question both the logic and the empirical validity of the proposition that a universalistic recipe of policy reform is the appropriate solution to re-ignite growth in the crisis-affected East Asian economies.

The advocates of the Washington consensus claim that '...the best available evidence shows ... the current wave of globalisation, which started around 1980, has actually promoted equality and reduced poverty' [italics added] [Dollar and Kraay, 2002:1]. Yet, these claims have to be juxtaposed with growing concerns about recent international and regional trends. Consider the following stylised facts.

- Recent research shows that there has been a world-wide growth slow-down in the 1980s and 1990s vis-à-vis the 1960s and 1970s, despite some notable exceptions, such as China - see Milanovic [2002]; Weisbrot et al [2000]; and Islam [2003].

- Some studies maintain that growth slow-down in developing countries is closely linked to growth slow-down in the OECD, rather than a deterioration in the policy environment of the average developing country [Easterly 2001].

- When China is excluded from the estimates, the 1990s show an increase in the absolute number in poverty across the world [UNDP, 2002: 18]

- An UNCTAD [2002] study paints a grim picture of persistent and rising poverty among the least developed countries.

- Serious concerns have been raised about the reliability of global statistics on poverty - see Deaton [2002] and Pogge and Reddy [2002].

- Some studies maintain that global inequality has gone up in the $1980 \mathrm{~s}$ and 1990s [Wade 2002a, 2002b;Milanovic, 2003], ${ }^{8}$ although a lot depends on the particular dimension of global inequality that is being measured [Ghose [2001]. At the very least, one can infer that the evidence on trends in global inequality is contested.

- A study based on 73 countries [representing 80 per cent of the world's population] for which reliable data exists show an increase in inequality since the 1950s in 48 cases [Cornia and Court, 2001].

Indeed, there are conspicuous cases of regions in distress that go against the prescriptions of orthodoxy. Thus: 
- Latin America represents a case of 'reforms without results'. Despite decades of reforms, poverty in Latin America today is higher than in 1980, real wages are barely equal to 1980 and inequality remains persistent and conspicuously high. ${ }^{9}$

- The attempt at 'big-bang' privatisation and fast-tracking of capitalism in the transition economies of Eastern Europe and Former Soviet Union have turned out to be a tragic failure. The 'transition recessions' have been longer and deeper than the Great Depression. GDP in 2000 was still below the 1990 level [by as much as 40 per cent] for many of these economies. Poverty and inequality have gone up sharply. ${ }^{10}$

It can also be demonstrated that the empirical foundation on which some basic tenets of the Washington consensus rests - most notably trade liberalisation and macroeconomic conservatism - are quite fragile. As Rodrik [2001] has shown, the voluminous empirical literature on trade and growth conflate outcomes with policy variables. Trade volumes are outcomes of both trade and non-trade policies. A better approximation of trade policies is tariff and non-tariff barriers, compliance with WTO regulations and so forth. When tariffs, for example, are used in simple, cross-country regressions to 'explain' growth, no statistically significant result emerges. Indeed, the association seems to be positive, with higher economic growth being correlated with greater propensity to trade. This may simply be capturing the well-known historical pattern that many countries initially grow under relatively protected domestic markets. As they get richer, they begin to liberalise their trade regime.

Recent studies that are sympathetic to the neoliberal ideas of the Washington Consensus have also failed to identify any meaningful impact of trade [as conventionally measured in terms of trade volume as a proportion of GDP] on both growth and poverty [as measured in terms of the average income of the poorest 20 per cent of the population]. For example, in a cross-country econometric study that received considerable publicity in the international media, Dollar and Kraay [2000] failed to demonstrate a statistically significant impact of trade performance of countries on the average income of the poor. ${ }^{11}$ A similar finding is reported in an IMF study [Ghura et al, 2002].

As is well known, the role of macroeconomic prudence in engendering national economic prosperity receives pride of place in the original version of the Washington Consensus [see Table 1]. Yet, the empirical evidence corroborating a link between macroeconomic conservatism [as reflected in fiscal prudence and the single-minded pursuit of low inflation], growth and poverty is tenuous. Based on the available literature and some estimates done by the authors [Islam 2003], one can highlight the following stylised facts.

- Macroeconomic conservatism implicitly focuses on 'special cases' because it is a story of the misfortunes that await countries if they engage in macroeconomic extremes. ${ }^{12}$ 
- Moderate rates of inflation are not harmful to growth. Inflation rates need to be quite high [in the 15 to 40 per cent range] before they become prejudicial to growth [Bruno and Easterly 1995].

- Studies using OECD data also show that countries that aimed for very low rates of inflation [0-3 per cent] do not necessarily exhibit either lower inflation or lower unemployment than countries that did not adopt inflation targeting [see, for example, Debelle et al 1998].

- While some studies have demonstrated a statistical link between fiscal deficits and poor growth performance, others focusing on both poverty and growth have not been able to endorse the findings. More specifically, there is no statistical link between fiscal deficits and higher incidence of poverty [Dollar and Kray 2000].

- Some studies have demonstrated that inflation has a negative impact on the living standards of the poor, but the estimated elasticities are quite low and can be easily offset by countervailing factors. For example, a 1 per cent increase in inflation leads to a 0.01 per cent decline in the average income of the poor, but a 1 per cent increase in per capita GDP leads to a 0.94 per cent increase in the average income of the poor [Ghura et al 2002].

- While growth is a key determinant of the incidence of poverty, it can be offset by rising inequality [Ghura et al 2002]. Hence, what matters to poverty reduction is equitable growth rather than the single-minded pursuit of fiscal prudence or low inflation.

- Cross-country econometric estimates are sensitive to the nature of the data [in terms of variations in time-periods and sample size] raising doubts about their credibility as a source of policy advice. There is no alternative to in-depth studies of the experiences of individual countries or a specific set of countries [Cashin et al 2001].

In sum, it is difficult to argue that the empirical foundation of global neoliberalism is so robust that one can confidently prescribe a 'one-size-fits-all' policy agenda for East Asia as well as other developing regions of the world. In any case, the view that the East Asian crisis was fundamentally driven by internal structural deficiencies that require large-scale reforms to rectify is highly contested. Stiglitz [2002] and others, such as the ADB-supported Asia Policy Forum [ADB, 2000], argue that the crisisaffected economies of the region were, to a significant extent, the victims of instability in unfettered short-term capital flows.

Even if post-crisis East Asia has to undertake a process of policy reform, does this mean that the 'augmented' Washington consensus offers the best guide? Dissident economists reject this option. Rodrik [2002a], for example, regards the 'augmented Washington consensus' as a fundamental misconception. The flawed nature of the augmented version of the Washington consensus stems from the fact that '...it is an impossibly broad, undifferentiated agenda of...reform' [Rodrik 2002a:1]. It ends up 
describing the desirable features of development but does not suggest a feasible way of getting there

What about the renewed commitment to poverty and the notion that it should play a central role in national development strategies? One can hardly question the view that a renewed commitment to eradicating poverty lies at the core of engendering and sustaining development, especially for such developing East Asian economies as Indonesia and Thailand. Indeed, at a UN summit in September 2000, more than 180 countries forged a consensus that the international community should commit itself to the attainment of target reductions in both the income and non-income dimensions of poverty by 2015 [using 1990 as the base]. ${ }^{13}$ What is debatable, however, is the specific approach that the Bretton Woods institutions have taken in incorporating the idea that poverty reduction should play a central role in national development strategies in East Asia and elsewhere. These institutions are expected to play a leading role in the propagation of so-called 'PRSPs' or 'poverty reduction strategy papers ' that developing countries must enunciate and implement through a nationally-owned, participatory process in order to gain access to development assistance. East Asian countries have not been immune to this new approach, with Indonesia releasing its 'interim' PRSP in October 2002 and thus joining the ranks of about 70 countries that have done so.

Critics of the PRSP maintain that the process will simply be dragged into a bureaucratic quagmire [Easterly, 2002]. Preliminary evaluations by the IMF and ILO of the 'first generation' PRSPs do not inspire much confidence. ILO [2002b] maintains in many countries employment concerns were not highlighted. The IMF evaluation [Ames et al 2002] notes that, in many countries, '...the PRSP process produced extensive lists of goals and ... even longer lists of actions in support of those goals'. The authors of the review note that '...trade-offs and prioritisations are clearly needed if the strategy is to be realistic'. At the same time, the authors concede that ' ...the PRSP countries often find it difficult to set priorities in the face of uncertainties regarding their overall growth strategy, the cost of various actions and their own budget constraints'. They also highlight concerns of developing country governments that the '...procedures and reporting requirements associated with PRSP-lending operations remain overly demanding.' Developing country representatives, both from the government and civil society, also '... pointed to continuing tensions between the principle of country ownership and the tendency of donors to promote issues of importance to themselves...' The reviewers conclude that'...more information on aid commitments and more predictable aid flows would help low-income countries plan and implement their own strategies' [Ames et al 2002:3-4].

\section{Resisting neoliberalism in East Asia}

Capitalism in East Asia is generally organised very differently from the apolitical idealisations found in much of the IFI's prescriptive literature. Moreover, the specific patterns of business-government connections, corporate organisation, and broader social relations that are now routinely identified in the increasingly sophisticated and extensive comparative literature on East Asian political-economies, ${ }^{14}$ draw attention not just to their distinctiveness, but also to their durability. This is not surprising. The contingent institutional structures associated with political rule and business 
organisation in East Asia not only provide a continuing template for social relationships, they are themselves an expression of earlier social and political accommodations [Beeson 2002]. Put differently, policy-making processes in particular and the determination of economic structures and relationships more generally have what Hall [1986: 5] describes as an inherent 'institutional logic' that effectively delimits the range of possible outcomes. In such circumstances, even if it could be determined that a policy paradigm was outdated, dysfunctional or otherwise inappropriate, it is entirely possible that institutional inertia will inhibit change [Goldstein and Keohane 1993: 3-30].

The most important exemplar of this possibility is, of course, Japan. It is now commonplace to draw attention to the seeming exhaustion of the developmental state model in Japan, and to note the way in which former sources of competitive advantage have now become liabilities [Katz 1998]. The Japanese case does illustrate the way that institutionalised patterns of relationships can become self-serving and actually contribute to the very problems they are meant to address. And yet there are a number of important caveats that ought to be added to this picture of decline and institutional ossification. First, the Japanese developmental state has achieved its purpose in ways that other nations of the region have not, and, for many states in the region, an approximation of the development state may still offer the best way of overcoming the handicaps of 'late' development. Second, even if Japanese planners appear bereft of the ideas and authority necessary to turnaround Japan's lacklustre economic performance, institutional inertia makes any radical change unlikely. Third, and perhaps most germane to this discussion, it is far from clear that the intellectual debate about the possible merits of neoliberal reform has been won in Japan. Not only are there still doubts about just how exhausted the Japanese model actually is [Fingleton 2002], but there has been a widespread sense of Schadenfreude amongst the Japanese about the troubles that are currently gripping the American economy [Ibison 2002]. The significance of such sentiments should not be underestimated, especially at the elite level, for as the controversy over the World Bank's landmark analysis of the 'Asian miracle' reminds us, the struggle for contest to create the conventional wisdom is a deeply political process and dependent on the resources that can be deployed. ${ }^{15}$ Significantly, in the aftermath of the recent financial crisis when its leadership aspirations were abruptly undercut by the combined actions of the US and the IMF, Japan has finally begun to show signs of assuming the sort of regional leadership role its economic position dictates [Bowles 2002: 244-270].

Other countries, of course, do not have Japan's economic weight or potential political leverage. Nevertheless, there are important examples of widespread resistance to neoliberal reform. The most consistent criticism has come from Malaysian Prime Minister Mahathir Mohammad. ${ }^{16}$ Admittedly, he is widely vilified in 'the West' and is tainted by his personal association with a repressive, authoritarian form of government. Despite these important reservations, one has to concede that he makes a number of points that have significant support across the region. Central to Mahathir's critique of 'the West' generally and the IFIs in particular is his claim that the IFI 'favour the big and the financially rich corporations and discriminate against the small and poor businesses from developing countries. So the dice is [sic] loaded against the poor developing countries' [Mahathir 2003]. Mahathir believes that only the collective actions of developing countries are likely to provide a bulwark against neoliberal hegemony. Although his government may have had powerful incentives to 
resist a neoliberal reform agenda that implicitly threatens the interlocking patterns of political and economic power underpinning his administration [Beeson 2000: 335-51], it is also important to recognise that his views have a sympathetic audience in the region.

\section{Beyond neoliberalism in East Asia}

Tinkering with an 'augmented Washington consensus' in East Asia and elsewhere is unlikely to yield a novel and pragmatic alternative to neoliberalism. What, then, is the way forward? One should start from the premise that the broad principles of mainstream economics, rather than the particular prescriptions of neoliberalism, are relevant in guiding economic development. This means that one cannot retreat to the state activism of the past or uncritically embrace its modern equivalent, the street protests underpinning the 'anti-globalisation' movement that erupted in Seattle and elsewhere. ${ }^{17}$ This means too that one cannot condone East Asian-style governance of the past entailing attenuation of human rights and the corrupt nature of 'crony capitalism'. Whether or not non-democratic regimes and so-called close governmentbusiness relations unleashed a virtuous cycle of growth will always remain debatable. What is clear is that, in a new international environment in which there is a low degree of tolerance for both corruption and abuse of human rights, the policy-makers of East Asia in the post-crisis era will have to make a fresh start.

In making a fresh start, policymakers in East Asia should espouse the broad principles of mainstream economics that allow scope for institutional eclecticism. In other words, it is necessary to move away from the formulaic principles that drove the Washington Consensus and rediscover the virtues of a mixed economy model with its many institutional variants. ${ }^{18}$ This means that both states and markets have critical roles to play in economic development. The appropriate combination of the two varies over time and across countries. Hence, it is necessary to devise context-specific approaches to deal with problems of poverty, inequality and sustainable development.

East Asian policymakers should also recognise that there is likely to be a trade-off between the imperatives of globalisation and domestic democratic politics. When they gear their entire national development strategy to the preferences and sentiments of global markets - often subsumed under the rubric of attracting and sustaining investor confidence - they may be forced to shun the voices and concerns of domestic constituencies and the strategic directions that a nation ought to take. This inadvertently undermines democratic governance and may well cause the tensions between domestic stakeholders and foreign constituencies to become unmanageable. Under such circumstances, crafting a credible national development strategy becomes rather difficult. ${ }^{19}$

Despite the commendable attempts that the IFIs have made in recent years to improve transparency and accountability in their operations and decisions, a growing number of influential voices are now arguing that, to remain at the forefront of development policy and practice, institutions of global economic governance, most notably the IFIs, must confront their impaired legitimacy. ${ }^{20}$ The thesis of impaired legitimacy starts from the premise that the prevailing ownership structure of the IFIs, in which rich countries are disproportionately favoured by the current voting formula, creates 
powerful incentives for the G-7 nations, and the US in particular, to pursue their commercial and national interests often at the expense of the interests of developing countries. This pursuit of self -interest is usually cloaked in the language of the Washington Consensus, suggesting that there is a universally agreed set of ideas on what constitutes a national development agenda. One solution, some argue, lies in changing the voting formula so that the developing countries have more influence over the IFIs. Yet another is to disband the durable, but entirely undemocratic, practice whereby the head of the World Bank is chosen by the US and the head of IMF is chosen by the North Western European nations.

Others have argued that that there should be clear separation between policy analyses, research and the operational activities of the IFIs by ensuring that the former are carried out by independent agencies. Currently, the research departments are located within these institutions, creating the risk that some of the politically sensitive policyoriented research could be used to justify the operational imperatives of the World Bank and IMF. ${ }^{21}$ Critics maintain that it is through the lending operations and 'country assistance strategies' that the largest shareholders of the two institutions seek to exercise their strategic influence. While it is easy to dismiss the above proposals as too contentious and hence unlikely to be ever seriously considered by the international community, what is clear is the need to move away from an artificial consensus on global policy issues. It is necessary to nourish the spirit of eclecticism and intellectual diversity anchored in the idea of country-specific approaches to development in the post-crisis era.

The papers in this collection indicate that the countries of the region have responded to the neoliberal agenda in a variety of ways, reminding us of the continuing capacity states have to mediate external influences [Weiss 2003]. What is most striking in the aftermath of the East Asian economic crisis, however, is the increasing desire to create regional mechanisms capable of responding to long-run structural changes in the international economy and the IFI-sponsored political interventions that accompany them. Whatever else the crisis revealed, it demonstrated the region's collective vulnerability to externally-generated economic forces, and to extra-regional political actors that sought to manage them. In such circumstances, it is revealing that there have been a series of major regional initiatives to develop monetary mechanisms like the proposed Asian Monetary Fund [AMF] to insulate the region from damaging economic forces, and political initiatives like 'ASEAN +3 ' to provide a counterweight to the overweening influence of the US and the IFIs [Webber 2001: 339-372]. The idea was first mooted with the onset of the 1997 financial crisis in East Asia and took the form of a proposed Asian Monetary Fund [AMF] to supplement the financing facilities available through the IMF. The proposal was shot down by the IMF, European Union and the United States on the ground that it would duplicate the activities of the IMF and that a regional body along the lines of the AMF would lack the political will to ask member countries to undertake unpopular adjustment measures to cope with macroeconomic crises. Recent developments suggest that the idea of a regional financial architecture to supplement conventional multilateral arrangements is emerging with renewed vigour [see Rana, 2002].

\section{Concluding remarks}


Crafting pragmatic alternatives to neoliberalism that will facilitate pro-poor, employment-friendly development agenda at the national level will require an environment in which developing countries in East Asia and elsewhere can harness an increased inflow of external resources to meet national development goals through both aid and access to export markets of the rich nations. Access to such markets depends not just on dismantling trade barriers by both rich and poor countries, but also on the ability of the developed world to create the necessary demand for developing country exports. This means fostering and sustaining buoyant domestic markets in the industrialised countries - a task that surely belongs to the domain of macroeconomic policy. After all, a key lesson is that the growth slow-down in the developing world in the 1980s and 1990s is linked to the growth slow-down in the OECD [Easterly 2001]. Trade flows would have to be complemented by appropriate aid flows. Current calculations suggest that annual flows of development assistance will have to double from present annual flows of US\$40 to 56 billion if the world community wishes to make a credible commitment to financing the Millennium Development Goals [UNDP [2002:31]. At the same time, renewed efforts will have to be made in ensuring that the available quantum of aid is allocated to priority areas that directly affect growth, employment creation, and poverty. The rich nations of the world have to make a commitment to 'development-friendly' policies. Currently, the rich economies that matter in development cooperation - such as the United States compare very unfavourably with the generosity of such small European nations as Denmark and the Netherlands. ${ }^{22}$

And yet this alternative agenda is unlikely to be realised. Such outcomes would require extensive international cooperation and the existence of states with the capacity to effectively implement more expansionary and 'development-friendly' policies. Not only are the IFIs unlikely to support such initiatives, but the distinctive and central role played by the region's interventionist, developmental states is actively discouraged by neoliberal reforms. In such circumstances, if the states of East Asia are to create an environment in which continuing economic development is feasible, they may have to pursue nationally or regionally-based strategies that either reject or deflect some of the key elements of the neoliberal reform package. The danger, of course, is that such a project will simply be a mechanism for propping up or legitimating incompetent or corrupt administrations. The challenge for the region, in short, is to revitalise some of the former strengths of the development state without succumbing to cronyism and inefficiency, while simultaneously warding off inappropriate reformist pressures from the IFIs. This is likely to be the defining policy challenge for East Asian political elites in the twenty-first century.

\section{References}

ADB,1997 Emerging Asia: Changes and Challenges, Manila: Asian Development

Bank.

ADB, 2000, Asia Policy Forum, Manila: Asian Development Bank.

Ames, B, Bhatt, G and Plant, M 2002 'Taking Stock of Poverty Reduction Efforts', Finance and Development, Vol.39, No.2.

Bauer, P.,1972, Dissent on Development, London: Weidenfield and Nicholson 
Bauer, P., 1984, Reality and Rhetoric: Studies in the Economics of Development, London: Weidenfield and Nicholson

Beeson, M. and Bell, S., forthcoming, 'The strong and the weak in world capitalisms: Structures, institutions and agency in the international political economy', in Phillips, Nicola [ed.], Globalising IPE, London: Palgrave. Available at http://eprint.uq.edu.au/archive/00000341/

Beeson, M., 2000, 'Mahathir and the markets: Globalisation and the pursuit of economic autonomy in Malaysia', Pacific Affairs, Vol. 73, No. 3.

Beeson, M., 2001, 'Globalisation, governance, and the political-economy of public policy reform in East Asia', Governance: An International Journal of Policy, Administration and Institutions, Vol.14, No.4.

Beeson, M., 2002, 'Theorising Institutional Change in East Asia', in Beeson, M. [ed.], Reconfiguring East Asia: Regional Institutions and Organisations After the Crisis, London: Curzon Press.

Beeson, M., forthcoming, 'East Asia, the International Financial Institutions and Regional Regulatory Reform: A review of the issues', Journal of the Asia Pacific Economy.

Bello, W., 1998, 'East Asia: On the Eve of the Great Transformation?', Review of International Political Economy, Vol .5 No.3.

Berger, S. and Dore, R., [eds.], 1996, National Diversity and Global Capitalism, Ithaca: Cornell University Press.

Block, F., 1990, Post-Industrial Possibilities: A Critique of Economic Discourse, Berkeley: University of California Press.

Bowles, P., 2002, 'Asia's post-crisis regionalism: Bringing the state back in, keeping the [United] States out', Review of International Political Economy, Vol. 9, No. 2.

Bruno, M and Easterly, W., 1995, 'Inflation Crises and Long-Run Growth', Journal of Monetary Economics, Vol.41, February.

Camdessus, M., 1997, Globalization and Asia: The Challenges for Regional Integration and the Implications for Hong Kong, Conference Address, March 7, Hong Kong.

Cashin, P et al., 2001, 'Macroeconomic Policies and Poverty Reduction: Stylised Facts and an Overview of Research', IMF Working Paper, WP/01/135, September.

Centre for Global Policy Development and Foreign Policy.,2003, 'Ranking the rich', Foreign Policy, May/June

Chang, H-J., 2002, 'Kicking away the Ladder: An Unofficial History of Capitalism, especially in Britain and the United States', Challenge, Vol. 45 No. 5. 
Chomsky, N., 1993, 'The Clinton Vision', Z Magazine, December: 1-13

Coates, D., 2000, Models of Capitalism, Oxford: Polity Press.

Cockett, R., 1994, Thinking the Unthinkable: Think-Tanks and the Economic Counter-Revolution 1931-1983, New York: Harper Collins.

Cohen, S., 2000, 'American Journalism and Russia's Tragedy', The Nation, October2.

Cornia, G.V. and Court, J 2001 'Inequality, Growth and Poverty in the Era of Liberalisation and Globalisation', Policy Brief No. 4, Helsinki: World Institute for Development Economics Research, Finland.

Deaton, A., 2002, 'Is World Poverty Falling'? Finance and Development, Vol.39, No. 2.

Debelle, G et al., 1998, 'Inflation Targeting as a Framework for Monetary Policy', Economic Issues, No.5.

Dollar, D and Kraay, A., 2000, 'Growth is Good for the Poor', Policy Research Working Paper No. 2587, World Bank.

Dowrick, S and Akmal, M., 2003, 'Explaining Contradictory Trends in Global Income Inequality: A Tale of Two Biases', mimeo, Faculty of Economics and Commerce, Australian National University. Presented at a Workshop on 'Benefits and Costs of Globalisation in the Asia-Pacific', Griffith University, Brisbane, February 13-14.

Easterly, W., 2001, 'The Lost Decades: Developing Countries Stagnation in spite of Policy Reform 1980-1983', February, mimeo, World Bank: Washington DC.

Equidad.2000 'Poverty and Inequality: Recent Trends', InterAmerican Development Bank, March.

Fingleton, E. 2002, 'Is Japan Faking it?’, Financial Review, November 22.

Fischer, F., 1990, Technocracy and the Politics of Expertise, California: Sage Publications.

Ghura, D, Leite, C and Tsangaridies, C., 2002, 'Is Growth Enough? Macroeconomic Policy and Poverty Reduction', IMF Working Paper, WP/02/118, July.

Glyn, A., 1990, 'The rise and fall of the Golden Age', in Marglin, S. A. and Schor, J. B. [eds.], The Golden Age of Capitalism: Reinterpreting the Postwar Experience, Oxford: Clarendon Press 
Goldstein, J. and Keohane, R., 1993, 'Ideas and Foreign policy: An Analytical Framework', in Goldstein, J. and Keohane, R. [eds.] Ideas and Foreign Policy: Beliefs, Institutions and Political Change, Ithaca: Cornell University Press.

Hall, P., 1986, Governing the Economy: The Politics of State Intervention in Britain and France, New York: Oxford University Press.

Hall, P., 1993, 'Policy Paradigms, Social Learning, and the State: The Case of Economic Policymaking in Britain', Comparative Politics, Vol. 25 No.3.

Hall, P., and Soskice, D., [eds.], 2001, Varieties of Capitalism: The Institutional Foundations of Comparative Advantage, [Oxford: Oxford University Press].

Higgott, R. 2000, 'Contested Globalization: The Changing Context and Normative Challenges', Review of International Studies, Vol. 26.

Ibison, D., 2002, 'Japanese Delight as Scandals Rock the "American model”, Financial Times, August 15.

ILO, 2002a, Globalisation and Decent Work in the Americas: Report of the Director General, $15^{\text {th }}$ American Regional Meeting, Lima, December.

ILO, 2002b, 'Poverty Reduction Strategy Papers PRSPs : An Assessment of the ILO Experience', mimeo, November, Geneva.

InterAmerican Development Bank 1997 A Decade of Structural Reforms: No Pain, No Gain? Part Two, Washington DC.

Islam, I and Chowdhury, A., 2000, The Political Economy of East Asia: Post-Crisis Debates, Melbourne and Oxford: Oxford University Press

Islam, I., 2003, 'Avoiding the Stabilisation trap: Macroeconomic Policy for Growth, Employment and Poverty Reduction', April, Employment Strategy Department, Geneva: ILO.

Jayasuriya, K. and Rosser, A., 2001, 'Economic Orthodoxy and the East Asian crisis', Third World Quarterly, Vol. 22, No. 3.

Kanbur, R., 1999, 'The Strange Case of the Washington Consensus', mimeo, Cornell University

Kanbur, R., 2002, 'IFIs and IPGs: Operational Implications for the World Bank', mimeo, Cornell University, June, paper prepared for the G24 Technical Group Meeting, Beirut, March 1-2.

Kapur, D., 2002, 'Do as I say, Not as I do', Working Paper No.16, October, Washington DC: Center for Global Development.

Katz, R., 1998, Japan, The System That Soured: The Rise and fall of the Japanese Economic Miracle, Armonk: M.E. Sharpe. 
Kolodko, G.W., 1999, 'Ten Years of Post-Socialist Transition: Lessons for Policy Reform', World Bank Policy Research Working Paper, No.2095, April, Washington DC: World Bank

Krueger, A., 1974, 'The Political Economy of the Rent-Seeking Society', American Economic Review, Vol.64, No.3

Krueger, A., 1990, 'Government Failures in Development', Journal of Economic Perspectives, Vol.3, No.4

Kuttner, R.,1997, Everything for Sale: The Virtues and Limits of Markets, New York: Alfred A Knopf.

Lal, D., 1983, The Poverty of Development Economics, Hobart Paperback, No.16, London: Institute of Economic Affairs

Latham, R., 1997, The Liberal moment: Modernity, Security, and the Making of Postwar International Order, New York: Columbia University Press.

Lustig, N and Arias, O., 2000, ' Poverty and Inequality Trends in Latin America and the Caribbean, March, Finance and Development.

Milanovic, B., 2003, 'Worlds Apart: Global Inequality 1950-2000', mimeo, World Bank, presented at a Workshop on 'The Benefits and Costs of Globalisation in the Asia-Pacific', Griffith University, Brisbane, February 13-14.

OECD,1996, Shaping the $21^{\text {st }}$ Century: The Contribution of Development Cooperation, DAC, Paris: OECD.

Pauly, L W., 1997, Who Elected the Bankers? Surveillance and Control in the World Economy, Ithaca: Cornell University Press.

Pincus, J.R. and Winters, J. eds.,2002, Re-inventing the World Bank, Ithaca: Cornell University Press.

Philips, K., 2002, 'The Cycles of Financial Scandals', The New York Times, July 17.

Pogge, T.W and Reddy, S., 2002, 'Unknown: the Extent, Distribution and Trend of Global Income Poverty', mimeo, August 16, Columbia University.

Rana, P.B., 2002, 'Monetary and Financial Cooperation in East Asia: The Chiang Mai Initiative and Beyond', ERD Working Paper No.6, Manila: ADB.

Ravenhill, J., 2002, 'A Three Bloc World? The New East Asian regionalism', International Relations of the Asia Pacific, Vol. 2.

Rodrik, D 2001 'The Global Governance of Trade as if Development Really Mattered', Background Paper, October, New York, UNDP 
Rodrik, D., 2002a, 'After Neoliberalism, What?', mimeo, June, Harvard University, paper presented at a conference on 'Alternatives to Neoliberalism', Washington DC, May 23

Rodrik, D, 2002b, 'Feasible Globalisations', mimeo, June, Harvard University.

Ruggie, J. G., 1982, 'International Regimes, Transactions and Change: Embedded Liberalism in the PostWar Economic Order', International Organisation Vol. 36 No.2.

Sinclair, T., 2001, 'The infrastructure of global governance: Quasi-regulatory mechanisms and the new global finance', Global Governance, Vol., 7 No. 4.

Soros, G (1998) The Crisis of Global Capitalism, New York: Public Affairs

Stiglitz, J., 1998, 'More Instruments and Broader Goals: Moving Towards the PostWashington Consensus, 1998 WIDER Annual Lecture, Helsinki

Stiglitz, J., 2002, Globalisation and its Discontents, New York: WW Norton

Tabb, W. K., 1995, The Postwar Japanese System: Cultural Economy and Economic Transformation, New York: Oxford University Press.

UNCTAD, 2002 The Least Developed Countries Report, Geneva: UNCTAD.

UNDP, 2002 Human Development Report 2002, Oxford University Press and New York.

Wade, R., 2002b, 'Globalisation, Poverty and Income Distribution: Does the Liberal Argument Hold'? in Gruen, D; O'Brien, T and Lawson, J eds Globalisation, Living Standards and Inequality, Proceedings of a Conference, May 27-28, Reserve bank of Australia and Australian Treasury.

Wade, R.,1996, 'Japan, the World Bank, and the art of paradigm maintenance: The East Asian Miracle in political perspective', New Left Review, Vol. 217, May/June.

Wade, R.H.,2002a, ‘The Rising Inequality of World Income Distribution', Finance and Development, Vol. 38, No. 4.

Webber, D., 2001, 'Two Funerals and a Wedding? The Ups and Downs of Regionalism in East Asia and Asia-Pacific after the Asian crisis', The Pacific Review, Vol. 14, No. 3.

Weisbrot, M, Naiman, R and Kim, J., 2000, 'The Emperor Has No Growth: Declining Economic Growth Rates in the Era of Globalisation', September 26, Washington DC; Centre for Economic and Policy Research

Weiss, L., 2003, [ed.], States in the Global Economy: Bringing Domestic Institutions Back In, Cambridge: Cambridge University Press. 
Whitley, R., 1999, Divergent Capitalisms: The Social Structuring and Change of Business Systems, Oxford University Press.

Williamson, J 1999 'What Should the Bank Think About the Washington Consensus'? Paper Prepared as a background paper to the World Development Report 2000, July

Williamson, J., 2000, 'The Role of the IMF: A Guide to the Reports, International Economics Policy Briefs, Working Paper No 00-5, May, Institute for International Economics.

Williamson, J., 1994, 'In search of a manual for Technopols', in Williamson, J. [ed.], The Political Economy of Policy Reform, Washington: Institute for International Economics.

World Bank, 1993, The East Asian Miracle: Economic Growth and Public Policy, New York and Oxford: Oxford University Press

World Bank, 1997, World Development Report 1997: The State in a Changing World, Oxford: Oxford University Press.

World Bank, 2002, Transition: The First Ten Years - Analysis and Lessons from the Former Soviet Union and Eastern Europe, Washington DC : The World Bank

Zysman, J., 1994, 'How Institutions Create Historically Rooted Trajectories of Growth', Industrial and Corporate Change, Vol. 3 No.1. 
Table 1: Re-inventing neoliberalism: the 'augmented' Washington Consensus

\begin{tabular}{|c|c|}
\hline $\begin{array}{l}\text { Washington Consensus } \\
\text { [the original ten] }\end{array}$ & $\begin{array}{l}\text { Augmented Washington Consensus } \\
\text { [original ten plus...] }\end{array}$ \\
\hline 1. Fiscal discipline & $\begin{array}{l}\text { 11. Central bank independence and } \\
\text { inflation targeting }\end{array}$ \\
\hline $\begin{array}{l}\text { 2. Redirection of public expenditure } \\
\text { towards basic education, primary } \\
\text { health care, infrastructure }\end{array}$ & $\begin{array}{l}\text { 12. Reform of both public sector and } \\
\text { private sector governance }\end{array}$ \\
\hline 3. Tax reform & 13. Flexible labour markets \\
\hline 4. Interest rate liberalisation & $\begin{array}{l}\text { 14. WTO agreements and harmonisation } \\
\text { of national standards with international } \\
\text { standards in business and finance, but } \\
\text { with exceptions [most notably } \\
\text { environment and labour] }\end{array}$ \\
\hline 5. Competitive exchange rate & $\begin{array}{l}\text { 15. Strengthening national financial } \\
\text { systems to facilitate eventual capital } \\
\text { account liberalisation }\end{array}$ \\
\hline 6. Trade liberalisation & 16. Sustainable development \\
\hline 7. Liberalisation of FDI flows & $\begin{array}{l}\text { 17. Protecting the vulnerable through } \\
\text { safety nets }\end{array}$ \\
\hline 8. Privatisation & $\begin{array}{l}\text { 18. Poverty reduction strategy [PRSP and } \\
\text { [PRSF ] }\end{array}$ \\
\hline 9. Deregulation & 19. Country ownership of policy agenda \\
\hline 10. Secure property rights & 20. Democratic participation \\
\hline
\end{tabular}

Note: this is an amended version of a suggested interpretation offered by Rodrik [2002a: 10]. PRSP = poverty reduction strategy papers; PRSF $=$ poverty reduction strategy framework. The left-side column of the table is based on Williamson [1999]. 
${ }^{1}$ For the causes and implications of the spectacular collapse of such iconic US companies as Enron and Global Crossing, see Philips [2002].

2 The tragedy of the transition economies in Eastern Europe and the case of 'reforms without results' in Latin America are highlighted at a later stage in the paper, as is the global evidence on growth, inequality and poverty.

${ }^{3}$ For prominent examples of this analytical tradition, see Lal [1983], Bauer [1972,1984] and Krueger [1974, 1990].

${ }^{4}$ Even if there were to be a paradigm shift in East Asia and a more enthusiastic embrace of neoliberal ideas, that are major potential constraints on the ability of many governments in the region to implement such policies as they lack the governmental capacities and the rich infrastructure of private sector organisations that are fundamental to neoliberal governance in Western Europe. See Beeson [2001: 481-502].

${ }^{5}$ Williamson [1999] has lamented the fact that both reputable economists and populist commentators have abused his conception of the term 'Washington Consensus'. He argues that he never intended it to become a synonym for 'neoliberalism' or 'market fundamentalism'. He developed the term within the specific context of Latin America as the region struggled to come to terms with the debt crisis of the 1980s. The paper defends the use of Washington Consensus as a good approximation of the neoliberal consensus in the developing world. It draws on the rationale offered by Kanbur [1999] that, despite the subtleties embedded in the original intent of Williamson, critics of the Washington Consensus judged what they saw in practice. Kanbur maintains that practitioners from the BrettonWoods institutions used the notion of the Consensus to adopt an aggressive negotiating stance with (recalcitrant) developing countries.

${ }^{6}$ Rodrik [2001] coined the term the 'augmented Washington consensus', while Stiglitz [1998] talked about a 'post-Washington consensus'. He seems to have moved away from that idea in subsequent work.

${ }^{7}$ See Islam and Chowdhury [2000, Chapter 1] for a discussion of the emergence of the 'consensus' on the nature and causes of rapid growth in pre-crisis East Asia.

${ }^{8}$ Dowrick and Akmal [2003] suggest no discernible change in inequality, after correcting for 'biases' in current measurement of world distribution of income.

${ }^{9}$ See IDB [1997] and Equidad [2000]. See also Lustig and Arias [2000]. Updates are offered in ILO [2002a]

${ }^{10}$ See World Bank [2002], Stiglitz [1999] and Kolodko [1999]. Cohen [2000] provides a fascinating account of how the US media under the Clinton administration ignored - or at least downplayed - the social costs of the project of fast-tracking capitalism in Eastern Europe.

${ }^{11}$ Dollar and Kraay [2000]. Milanovic [2002] notes that the Dollar and Kraay findings were enthusiastically embraced by such influential publications as the Economist and the Financial Times and made no attempt to convey the tenuous nature of the empirical evidence.

${ }^{12}$ Cross-country data show that the majority of developing countries are not fiscally profligate nor are they prone to high inflation. See Islam [2003].

${ }^{13}$ OECD [1996] is the precursor to the Millennium Development Goals.

${ }^{14}$ For a example, see Whitley [1999]; Hall and Soskice [2001].

${ }^{15}$ The World Bank's [1993] seminal report was the subject of significant intellectual contestation between the US and Japan - the latter determined to have the role and possible advantages of the developmental state approach it pioneered acknowledged in a way that IFI publications had not previously dome. See Wade [1996: 3-36].

${ }^{16}$ Thailand under Thaksin is also a good example of an East Asian-style resistance to the neoliberal agenda. Hewison discusses the Thai experience in some detail in this volume.

${ }^{17}$ The street protests that spearheaded the current 'anti-globalisation movement' first emerged in spectacular fashion in December, 1999 and scuttled the WTO meeting in Seattle. Amartya Sen [2001] makes the important point that, by raising 'global doubts', the current 'anti-globalisation movement' may be forcing the international community to seek 'global solutions'. It is thus counter-productive to dismiss the anti-globalisation movement as the product of a ruffian fringe that the world's intellectual sages and political leaders ought to stand up against.

${ }^{18}$ See Kuttner [1997] for an elegant statement for the case of the eclectic mixed economy model.

${ }^{19}$ Rodrik [2002b] makes this argument forcefully.

${ }^{20}$ See, for example, UNDP [2002]. See also Stiglitz [2002]. Williamson [2000] offers a comprehensive guide to reform proposals pertaining to the IMF, while Pincus and Winters [2002] examine the 're- 
invention of the World Bank'. Kapur [2002] offers a critique of G-7 proposals to reform the 'multilateral development banks' [MDBs].

${ }^{21}$ Deaton [2002], Kanbur [2002] and Wade [2002b] make these suggestions.

${ }^{22}$ An innovative ranking of 21 rich nations were carried out by the Washington-based Center for Global Development [CGD] and the well-known journal Foreign Policy [FP] in terms of their commitment to development in areas of aid disbursement, trade policy, environmental policy, foreign investment in developing countries and support for peace-keeping operations in conflict-ridden areas of the world. The United States and Japan languish at the bottom of this league table. See [CGD/FP, 2003]. 